\title{
Ecology and Conservation of the Endangered Banteng (Bos javanicus) in Indonesia Tropical Lowland Forest
}

\author{
Dede Aulia Rahman ${ }^{1 *}$, Riki Herliansyah ${ }^{2}$, Puji Rianti ${ }^{3}$, Ujang Mamat Rahmat ${ }^{4}$, Asep Yayus Firdaus ${ }^{4}$, Mochamad \\ Syamsudin ${ }^{4}$ \\ ${ }^{1}$ Department of Forest Resources Conservation and Ecotourism, Faculty of Forestry, IPB University, Bogor, Indonesia \\ ${ }^{2}$ Department of Mathematics, Kalimantan Institute of Technology, Balikpapan, Indonesia \\ ${ }^{3}$ Department of Biology, Faculty of Mathematics and Natural Sciences, IPB University, Bogor, Indonesia \\ ${ }^{4}$ Ujung Kulon National Park, Pandeglang, Indonesia
}

ARTICLE INFO

Article history:

Received June 26, 2018

Received in revised form November 16, 2018

Accepted March 4, 2019

\section{KEYWORDS:}

Big mammals,

endangered species,

occupancy model,

behavioural

\begin{abstract}
Banteng, Bos javanicus, as wild cattle is a vital and importance source of germplasm in Indonesia. Various human activities currently threaten their conservation status. Nonetheless, no long-term monitoring programmes are in place for this species. Using distribution point and statistical analysis based on 46,116 camera trap days from December 2015 to January 2017, we aimed to provide habitat preferences, activity patterns and ecological data for banteng population in Ujung Kulon National Park (UKNP). It is the largest population of banteng in Indonesia and is living in a limited habitat area. According to the best occupancy model, the most suitable areas for this species were the secondary forest located at the center portion of UKNP. The presence of the invasive cluster sugar palm, Arenga obtusifolia, in dry season provides additional alternative food for banteng when its main food is scarcer in the forest. Banteng was cathemeral all year round, with the proportion of cathemeral records and the recording rate did not change with the protection of the level area, moon phase or season. To reduce the probability of encountering predators, banteng avoided the space use of dholes. Selection and avoidance of habitats was stronger than avoidance of the predator activity areas. Habitat competition from domestic cattle which grazed illegally in the national park appears to be a problem to the species since zoonosis appears from domestic cattle to banteng. Therefore, effective law enforcement and an adequate conservation strategy are required to eliminate the impacts of both direct and indirect threats.
\end{abstract}

\section{Introduction}

Besides habitat destruction, intrinsic factors such as low reproduction rates, low densities, and extensive area requirements cause a high level of threat in the medium-large bodied mammal populations (Ripple et al. 2015; De la Torre et al. 2018). Approximately 60\% of medium-large bodied ungulates are commonly faced dramatic population declines and habitat destruction and threatened with extinction (Ripple et al. 2015). Moreover, nine South East Asian ungulates species are listed as Critically Endangered (IUCN 2018). Several plants and wildlife species, mainly carnivores, are very dependent on the presence of ungulates species in nature. The

\footnotetext{
* Corresponding Author

E-mail Address: dede.auliarahman@gmail.com
}

loss of ungulate species will cause tiered effects on ecosystems and in the future may affect essential economic and social services for humans (Ripple et al. 2015; Ripple et al. 2016). Amid a variety of threats to species, an increase in long-term research that addresses conservation solutions for these mediumlarge mammals are needed, particularly for lesserknown or non-charismatic species (Rahman et al. 2018).

The natural history and conservation need of many tropical forests of ungulates are poorly known, particularly in Bos javanicus (banteng). This lack of knowledge is heavily impacted by the conversion and degradation of lowland forests and illegal hunting, commercial trade, and bush-meat consumption (Nowak 1999; Di Marco et al. 2014). Banteng has its crucial function in ecosystems as dispersal vectors of plant propagules and nutrients (Bakker et al. 
2015), key modifiers and maintainers of ecosystem dynamics and habitat complexity (Jones et al. 1994; Waldram et al. 2008), as well as prey for medium to large carnivores (Mondal et al. 2012; Pudyatmoko 2018; Rahman et al. 2018).

Banteng is a primitive ungulate with three subspecies and now are habituating the forests of Borneo, Java, and Bali in Indonesia. This species came from the mainland of Southeast Asia, particularly in Yunnan, Southern China through Peninsular Malaysia (Timmins et al. 2008). Today, banteng is extinct in South Malaysia, Bangladesh, and India (Medway 1969). Banteng is listing as an endangered species (the IUCN Red List; Gardner et al. 2016) and protected by Indonesian law (Peraturan Menteri Lingkungan Hidup dan Kehutanan Republik Indonesia No. P.106/MENLHK/SETJEN/KUM.1/12/2018; Indonesian Ministry of Environment and Forestry 2018) as Appendix I in CITES. Furthermore, Banteng is also listing as one of the 25 endangered species that need special attention to conservation (decree no. SK.180/ IV-KKH/2015; Indonesian Ministry of Environment and Forestry 2015).

Here, we analysed a long-term study of 14-months intensive camera trap recording on the ecology and behaviour of banteng in the lowland tropical forest, Ujung Kulon National Park (UKNP). We aimed to: (1) provide relative encounter rates for recorded species, (2) investigate which habitat and environmental factors influence relative encounter rates, (3) observed the different time uses by banteng in their activity to avoid dangerous encounters with potential predators, and (4) investigate activity patterns, social structure and reproductive patterns.

\section{Materials and Methods}

\subsection{Study Area}

UKNP is a remnant of ancient forests that survived after a major eruption of a super volcano of Krakatau and tsunami in 1883 (Hommel 1987; Fauzi and Stoops 2004), and still have a significant threat of natural catastrophes such as earthquakes (Giachetti et al. 2012). It has a secondary growth tropical lowland rainforest with four main habitat types (Figure 1) and highly rainfall seasonal monsoonal climate. Biodiversity on land are suffering from anthropogenic activities, whereas the largest carnivores Javan tiger, Panthera tigris sondaica, has been extirpated, while the two remaining carnivores are Javan leopard (Panthera pardus melas) and dholes (Cuon alpinus) (Rahman et al. 2018). In UKNP, banteng (Bos javanicus) is one of six ungulate species and most prominent endemic mammals. The population of banteng are believed to be small in the UKNP (Pudyatmoko 2005). In 1970, there were 13 locations known as banteng habitat in Java, whereas it shrinks into four locations which the most abundant population occurs in UKNP recorded in 1997 (in total 905 individuals; Pudyatmoko 2005).

\subsection{Database Collection}

We were superimposed $1 / \mathrm{km}^{2}$ grid cell with total 329 grids at the study area and place cameras as close as possible at each intersection between the horizontal and vertical lines which comprised the grid (Figure 2). We used 108 camera-traps

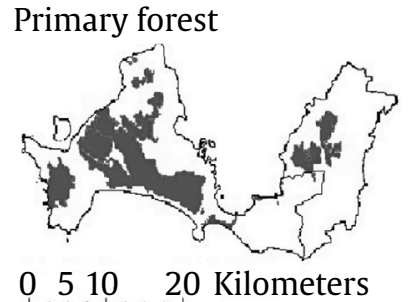

Mangrove-swap

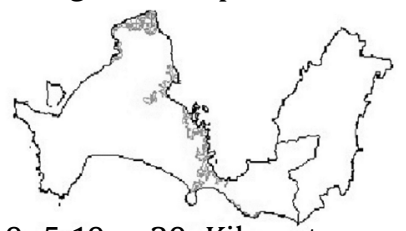

051020 Kilometers

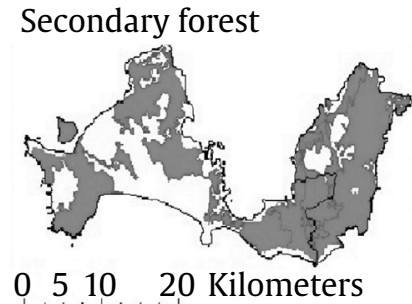

Beach forest

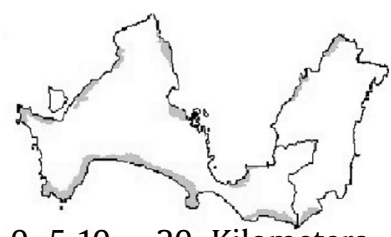

Figure 1. Four main habitat types in Ujung Kulon National Park

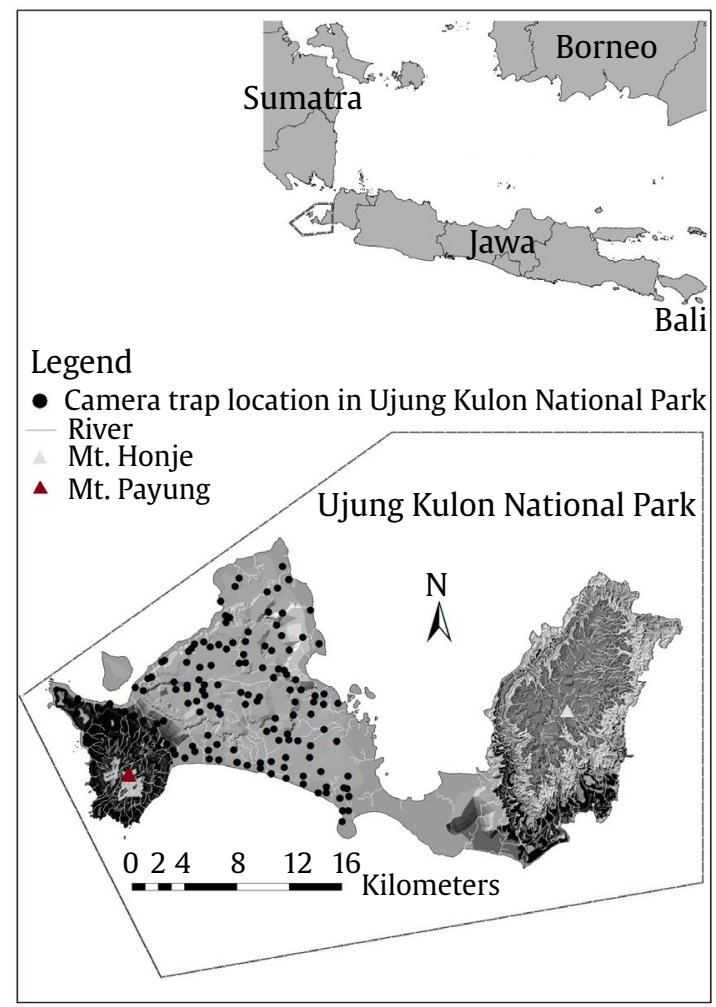

Figure 2. Camera trap locations in Ujung Kulon National Park (Java Island) 
(Bushnell Trophy Cam 119467 and Bushnell Trophy Cam 119405) between December 2015 to January 2017 (with sampling effort=46,116 trap days) and were set to detect animals throughout the 24-hour/ day, followed by c. sixty seconds of video, for each trigger. We set the time for every 10 seconds between successive triggers. We did not bait the camera, and all videos are with the information of date and time.

We randomly selected 134 sampling sites which designed represent all the four main vegetation types within UKNP. This scheme was designed to model the banteng's occupancy probability in the area UKNP, as well as documented its activity pattern. We were randomly drawn a grid over a digital map of the reserve and identified the sampling points by selecting its grid cells whereas at random one grid cell was one camera trap. This relatively even distribution of points within the UKNP maintained independence among points (a distance of $<1 \mathrm{~km}$ ). Cameras were set $170 \mathrm{~cm}$ above the ground with a 10-20 degree angle lead to the ground (following the standard design of camera trapping by the Rhino Monitoring Unit [RMU] team; Haryono et al. 2014). We did not consider any subsequent photograph of the same species which taken within 30 minutes interval as a new photographic event. Data were managed using camtrap R software (Niedballa et al. 2016). Each photograph was located using latitudelongitude coordinate and converted into digital data in GIS using the ArcMap program.

\subsection{Data Analysis}

\subsubsection{Relative Abundance Index}

We report relative abundance for banteng encountered using Relative Abundance Index (RAI). We define all detections for a specific species summed for all camera traps over all days, multiply it with 100 , and divide it by the total number of camera trap nights (O'Brien et al. 2003). Regarding un-normal distributed data or not transformed, we used nonparametric Kruskal Wallis tests and MannWhitney U post-hoc tests to check the differences in RAI between seasons.

\subsubsection{Landscape Covariates and Occupancy Models}

Fifteen variables were accounting for environmental traits, whereas four others for human impacts (Table 1). We tested the covariates for multicollinearity using Pearson's correlation matrix (STATS package R 3.1.1). We did not include covariates (with correlation $>0.5$ ) in the same candidate model.

Table 1. The environmental variables was considered to influence banteng distribution in Ujung Kulon National Park Environmental variables Variables Measured analysis

classification

Vegetation variables $\quad$ Distance to primary, secondary forest edge, distance to invasive of cluster sugar palm Arenga obtusifolia (langkap), and vegetation productivity

Geomorphology variables

Elevation, slope, and distance to nearest river

Predation

Climate variables
Distance to the nearest presence of $C$. alpinus and $P$. pardus melas

Annual rainfall, rainfall of the wettest month, rainfall of the driest month, annual mean temperature, the maximum temperature of the warmest month, and minimum temperature of the coldest month

Human impact variables

Distance to the nearest settlement, cultivated area, road, and illegal activity by human
Distance to the primary, secondary forest edge, and invasive of cluster sugar palm were extracted in ArcGIS 10.2.2, whilst vegetation productivity measured as the normalized difference vegetation index (NDVI, cf. Hansen et al. 2009)

The first two variables were computed on a $1 \mathrm{~km}^{2}$ grid resolution by averaging information extracted from a $90 \times 90 \mathrm{~m}$ Digital Elevation Model (DEM; Landsat 8) (http://earthexplorer.usgs.gov; http://srtm. csi.cgiar.org). Slopes were generated using slope function in ArcGIS (Jarvis et al. 2008). Distance to the nearest river was extracted in ArcGIS 10.2.2

Distance to the nearest presence of $C$. alpinus and $P$. pardus melas were extracted in ArcGIS 10.2.2

These variables, derived from monthly temperature and rainfall values recorded between 1950 and 2000 from a global network of climate stations, were downloaded from the WorldClim database (http://worldclim. org/bioclim). All layers were projected into WGS 1984 Zone 48 South

Distance to the nearest settlement, cultivated area, road, and illegal activity by human (UKNP 2017) were extracted in ArcGIS 10.2.2 
We classified camera-trapping data using 7-day intervals (26 occasions per season; Mackenzie et al. 2006). We estimated the site occupancy ( $\Psi)$ and detection probability ( $p$ ) for banteng with three possible results: (1) the site was occupied, and the banteng was detected ( $\Psi \times \mathrm{p}),(2)$ the banteng was present but not detected $(\Psi \times[1-p])$, and (3) the banteng was not present and not detected $(1-\Psi)$.

We sampled 26 occasions from each site and estimated its detection probabilities. We used a maximum likelihood estimation of the proportion of sites occupied $(\Psi)$ during the sample period as the projected parameter probabilities with a singleseason model, respectively in wet and dry seasons. Because banteng shows a slow reproductive cycle (approximately a 295-day gestation period), we assumed zero population rate throughout the entire sampling period (Nowak 1999).

Habitat preference identification were constructed by a set of 214 candidate models with four different approaches: (1) occupancy probability and detectability as constant across all sites, (2) variation in occupancy as a function of covariates, (3) variation in detectability as a function of covariates, and (4) both variation in occupancy and detectability as a function of covariates. This model allowed us to evaluate the differences in habitat occupancy as determined by a single covariate or a set of covariates, which would contribute to an improvement in the model's performance.

We used PRESENCE 11.1 software (Mackenzie and Royle 2005) for occupancy modelling, and it was run using 2000 bootstraps to assess the adjustment fit (P) and the overdispersion parameter ( $\hat{c})$. We also ranked the models by AIC adjusted for small sample size (AICc) following Burnham and Anderson (2002). All models with a $\triangle$ AICc value $<2$ were considered to be competitive. We also used the AICc weight (wi) for each model, which corresponds to the amount of evidence in favour of a given model, to choose the best model that we used to test our hypotheses.

\subsubsection{Temporal Interactions Between Banteng- Potential Predator}

The activity pattern of ungulates is strongly related to their predators (Dröge et al. 2017; Prugh et al. 2019). We followed Meredith and Ridout (2014) as a two-step procedure that resulted in a coefficient of overlap values from 0 (no overlap) to 1 (identical activity pattern). We used kernel density estimation or by fitting a distribution from the flexible class of non-negative trigonometric sum distributions (Fernández-Durán 2004). For the second step, we calculated the overlap between two estimated distributions using the coefficient of overlapping, $\Delta$ (Ridout and Linkie 2009). Here, we applied the $\Delta_{4}$ analysis because of the large sample size (Ridout and Linkie 2009; Meredith and Ridout 2014). We also used the overlap package (Meredith and Ridout 2014) to fit kernel density functions, estimate the coefficient of overlap, and calculate bootstrap estimates of the confidence intervals. We used Mardia-Watson-Wheeler Test (MWW test) to compare the distribution of detections across the diel cycle for all sampling campaign pairs, determining whether two activity patterns significantly differ (Batschelet 1981).

\subsubsection{Daily Activity Patterns, Group Size and Group Patterns}

Daily activity patterns and proportion of time spent active were estimated based on camera trap detections using Oriana circular statistics software (v4, Kovach Computing Services, Anglesey, UK) by applying the Rayleigh test (Batschelet 1981), the $\mathrm{R}$ package activity (Rowcliffe et al. 2014). We ran Wald tests for the statistical difference between activity level estimates at sunrise (dawn), sunset (dusk), noon and midnight. We used the Chi-square Test to see the frequency difference of observations between sunset-sunrise and between sunrise-sunset, with obtained timing from the Astronomical Applications Department of the US Naval Observatory (www. quickphase.com).

Furthermore, we used a moon calendar (Serrano 2011) to analyse the daily activity pattern on the lunar phase and continue with Analysis of Variance (ANOVA) to test the difference in activities rate between four moon phases $(F M=$ full moon, $F Q=$ first quarter, $\mathrm{LQ}=$ last quarter, and $\mathrm{NM}=$ new moon). We chose the two samples independent T-test to check whether there is a significant difference between activities on day and night as well as wet and dry seasons. To explain the distribution of activities in 24 hours, the effects of hours and night time (dummy variable where $D=1$ for $18.00-06.00$, otherwise $D=0$ ) and to describe the interaction among activities, Generalized Linear Latent Variable Models (GLLVMs), a statistical model with random effects similar to multivariate Generalized Linear Mixed Models 
(GLMMs), was used (Caraka et al. 2018). Warton et al. (2015) explained that the GLLVMs has several advantages in modelling multivariate-correlated responses compared to GLLMs; the number of parameters estimated is significantly smaller than that of GLLM due to the assumption imposed on GLLM to have an unstructured variance-covariance matrix. Besides, the latent variables used to incorporate correlation between responses can be used as a model-based approach to ordination. In this case, the responses are the number of Banteng activities including defecation, ingestive, locomotion, resting, social, and vigilant counted hourly (Table 2 ). Therefore, the multivariate responses are assumed to follow Poisson distribution. The mean responses and a linear predictor relationship are defined by:

$$
\mathrm{E}\left(Y_{i j}\right)=g\left(\mu_{i j}\right)=\eta_{i j}=\alpha_{i}+\boldsymbol{\beta}_{0 j}+\boldsymbol{x}_{i}^{\prime} \boldsymbol{\beta}_{j}+\boldsymbol{u}_{i}^{\prime} \lambda_{j}
$$

where $g($.$) was a link function corresponding$ to the selected distribution for responses, log link for the Poisson model. Latent variables, $u_{i}^{\prime}$ were assumed to have a standard normal distribution and independent of each other such that the variancecovariance matrix of random effects is $\Sigma=\lambda \lambda^{\prime} \lambda$. The term $\alpha_{i}$ was the row effects representing the site variation and treated as fixed effects (Hui et al. 2015). We then used a gllvm package from $\mathrm{R}$ for fitting the model (Niku et al. 2017). For analysing group sizes and group patterns, we use descriptive statistics unless indicated differently.

\section{Results}

\subsection{Relative Abundance Indices (RAI)}

We documented 3,259 photographs of banteng with 817 and 644 independent photographs in the wet $(\mathrm{RAI}=3.10)$ and dry season $(\mathrm{RAI}=3.24)$, respectively. There are no significant differences between the RAI of wet and dry seasons for banteng $(W=3,427 ; p=0.367)$.

\subsection{Landscape Covariates and Occupancy Models}

We observed the species in 96 (naive occupancy $=0.71$ and detectability $=0.52$ ) and 73 (naive occupancy $=0.54$ and detectability $=0.41$ ) of the 134 sites in wet and dry seasons, respectively. The center portion of UKNP resulted in the highest occupancy rates and detectability of bantengs ( $\Psi=0.58-0.95, \mathrm{p}=0.31-0.48 ; \Psi=0.44-0.88$, $\mathrm{p}=0.18-0.48$; for wet and dry season, respectively). The number was followed by the southern portion of $\operatorname{UKNP}(\Psi=0.32-0.43$, $\mathrm{p}=0.18-0.29 ; \Psi=0.29-0.38$, $\mathrm{p}=0.11$ 0.25 ; for wet and dry season, respectively). The west portion of UKNP showed the lowest occupancy rates
Table 2. Ethogram for Bos javanicus activity states used in the study

\begin{tabular}{|c|c|}
\hline Types of behaviour & Description \\
\hline Excretion & Defecating or urinating \\
\hline Locomotion & $\begin{array}{l}\text { Moving between foraging source or } \\
\text { within study area }\end{array}$ \\
\hline Ingestive & $\begin{array}{l}\text { Actively ingesting food or drink, or } \\
\text { processing (chewing) food items } \\
\text { during a grazing bout and or food } \\
\text { searching with head below the } \\
\text { vertebral column }\end{array}$ \\
\hline Resting & $\begin{array}{l}\text { Standing or sleeping in the sun or shade, } \\
\text { neither ruminating nor scanning } \\
\text { its environment }\end{array}$ \\
\hline Socializing & $\begin{array}{l}\text { Social interaction (necking), scratching, } \\
\text { stroking, massaging self or other, } \\
\text { nursing, and mating }\end{array}$ \\
\hline Vigilant & $\begin{array}{l}\text { Individuals scanning their surroundings } \\
\text { and exhibiting agonistic displays }\end{array}$ \\
\hline
\end{tabular}

and detectability $(\Psi=0.08-0.13, \mathrm{p}=0.06-0.09 ; \Psi=0.08$ 0.12 , $p=0.05-0.13$; for wet and dry season, respectively).

Our data best described the occupancy by two covariates in wet and dry seasons, respectively (Table 3 ). In wet season, distance to secondary forest edge had a negative relationship in which occupancy decreased as the distance to secondary forest edge increased ( $\Psi=0.01-0.98$; Figure 3a), followed by distance to illegal activity which had a positive relationship, in which occupancy by bantengs increased as the distance to illegal activity by human increased ( $\Psi=0.01-0.89$; Figure $3 \mathrm{~b}$ ). In dry season, distance to langkap had a negative relationship in which occupancy decreased as the distance to langkap increased ( $\Psi=0.18-0.88$; Figure $3 \mathrm{c}$ ), followed by distance to the nearest river which had a negative relationship, in which occupancy by bantengs decreased as the distance to the nearest river increased ( $\Psi=0.10-0.96$; Figure 3d). Furthermore, detectability was affected by four covariates in both wet (Figure 4a) and dry seasons (Figure 4b).

\subsection{Temporal Interactions Between Banteng- Potential Predator}

The results of the MWW test revealed that patterns of daily activities were significantly different in all pairs of species (Table 4, Figure 5). The values of temporal overlap coefficients were $<0.69$ for all pairs of animals, which means that there was either low or intermediate overlap in their activity patterns. The most similar is between banteng and dhole, which are cathemeral species. Banteng and Javan leopard presented different peak activities. The banteng was most active in early morning and late evening, whereas the peak activity of Javan leopard was in midday. 
Table 3. Occupancy models for Bantengs in the Ujung Kulon National Park, Indonesia, estimated by camera trapping between January and December 2016, grouped in sampling intervals of 7 consecutive days. With (.)=as constant, $\Psi=$ occupancy, $\mathrm{p}=$ detectability, AICw=Akaike weight, and $\mathrm{c}=$ dispersion parameter

\begin{tabular}{|c|c|c|c|c|}
\hline Model & AICc & $\triangle \mathrm{AICc}$ & $\mathrm{AIC} w$ & $\begin{array}{l}\text { Number of } \\
\text { parameters }\end{array}$ \\
\hline \multicolumn{5}{|l|}{ Wet } \\
\hline$\Psi$ (Secondary; illegalact); $p$ (primary; illegalact; cuon; secondary) & 568.90 & 0 & 0.30 & 8 \\
\hline$\Psi$ (Secondary; illegalact); $p$ (primary; cuon; secondary) & 570.48 & 1.58 & 0.18 & 7 \\
\hline$\Psi$ (Secondary; illegalact); $p$ (primary; illegalact; cuon) & 571.50 & 2.60 & 0.12 & 7 \\
\hline$\Psi$ (Secondary; illegalact); $p$ (primary; secondary) & 571.63 & 2.73 & 0.09 & 6 \\
\hline$\Psi$ (Secondary); $p$ (primary; illegalact) & 571.80 & 2.90 & 0.07 & 5 \\
\hline$\Psi$ (Secondary; illegalact); $p$ (cuon; secondary) & 572.30 & 3.40 & 0.06 & 6 \\
\hline$\Psi$ (Secondary); $p$ (cuon; primary) & 572.45 & 3.55 & 0.06 & 5 \\
\hline$\Psi$ (Illegalact); $p$ (cuon; primary) & 574.70 & 5.80 & 0.05 & 5 \\
\hline$\Psi$ (Illegalact); $p$ (primary) & 576.45 & 7.55 & 0.01 & 4 \\
\hline$\Psi$ (Secondary); $p$ (primary) & 580.32 & 11.42 & 0.001 & 4 \\
\hline$\Psi(.) ; p()$. & 580.79 & 11.89 & 0.001 & 2 \\
\hline$\Psi() ;$.$p (cuon; primary)$ & 581.40 & 12.50 & $<0.001$ & 3 \\
\hline$\Psi$ (Secondary); $p()$. & 581.84 & 12.94 & $<0.001$ & 3 \\
\hline$\Psi$ (Illegalact); $p()$. & 581.99 & 13.09 & $<0.001$ & 3 \\
\hline$\Psi() ;$.$p (primary)$ & 585.06 & 16.16 & $<0.001$ & 3 \\
\hline$\Psi(.) ; p($ cuon $)$ & 586.70 & 17.80 & $<0.001$ & 3 \\
\hline$\Psi$ (Primary; elevation); $p$ (primary) & 587.18 & 18.28 & $<0.001$ & 5 \\
\hline$\Psi($ Cuon $) ; p()$. & 587.60 & 18.70 & $<0.001$ & 3 \\
\hline$\Psi$ (Primary); $p()$. & 593.78 & 24.88 & $<0.001$ & 3 \\
\hline$\Psi$ (Elevation); $p()$. & 595.40 & 26.50 & $<0.001$ & 3 \\
\hline \multicolumn{5}{|l|}{ Dry } \\
\hline$\Psi$ (Langkap; river; primary); $p$ (primary; illegalact; cuon) & 522.76 & 0 & 0.77 & 8 \\
\hline$\Psi$ (Langkap; river; primary); $p$ (primary; river) & 523.81 & 1.05 & 0.41 & 7 \\
\hline$\Psi$ (Langkap; river; primary); $p$ (primary) & 524.42 & 1.66 & 0.13 & 6 \\
\hline$\Psi$ (Langkap; river); $p$ (primary) & 524.78 & 2.02 & 0.04 & 5 \\
\hline$\Psi$ (Langkap; river); $p$ (illegalact) & 525.20 & 2.44 & 0.03 & 5 \\
\hline$\Psi$ (Langkap); $p$ (primary; illegalact; cuon) & 527.13 & 4.37 & 0.006 & 6 \\
\hline$\Psi$ (Langkap; elevation; primary); $p$ (elevation; cuon; cultivated; illegalact) & 528.74 & 5.98 & 0.005 & 9 \\
\hline$\Psi$ (Primary); $p$ (cuon) & 531.30 & 8.54 & 0.003 & 4 \\
\hline$\Psi($ Cuon); $p()$. & 531.53 & 8.77 & 0.001 & 3 \\
\hline$\Psi$ (Cuon; elevation; primary); $p$ (primary; illegalact) & 532.98 & 10.22 & $<0.001$ & 7 \\
\hline$\Psi(.) ; p()$. & 534.24 & 11.48 & $<0.001$ & 2 \\
\hline$\Psi$ (Cultivated); $p()$. & 535.76 & 13.00 & $<0.001$ & 3 \\
\hline$\Psi$ (Elevation); $p()$. & 536.63 & 13.87 & $<0.001$ & 3 \\
\hline$\Psi$ (Elevation; langkap); $p$ (cultivated) & 538.78 & 16.02 & $<0.001$ & 5 \\
\hline$\Psi$ (Illegalact; cultivated); $p()$. & 541.01 & 18.25 & $<0.001$ & 4 \\
\hline$\Psi() ;$.$p (primary)$ & 541.76 & 19.00 & $<0.001$ & 3 \\
\hline$\Psi(.) ; p($ cuon $)$ & 543.08 & 20.32 & $<0.001$ & 3 \\
\hline$\Psi$ (Primary; cultivated); $p$ (primary; illegalact) & 544.30 & 21.54 & $<0.001$ & 6 \\
\hline$\Psi($ Cuon); $p()$. & 555.16 & 32.40 & $<0.001$ & 3 \\
\hline$\Psi$ (Primary); $p$ (cultivated) & 564.30 & 41.54 & $<0.001$ & 4 \\
\hline
\end{tabular}

\subsection{Daily Activity, Group Sizes and Group Patterns}

The number of activities is higher during the dry season compare to wet season, although there is no significant difference in the activity rate between these two seasons ( $\mathrm{t}=-1.988, \mathrm{df}=46, \mathrm{p}$-value $=0.052$ ). Numbers of banteng's records in wet and dry seasons $(\mathrm{n}=817$ and 644 , respectively) indicated a similar overall activity level in each season ( 0.72 and 0.68 , respectively). Also, there was no significant deviation has been detected from a uniform activity distribution throughout the day in both wet and dry seasons ( $z=3.13, p=0.101$ (Figure 6a); $z=5.43, p=0.455$ (Figure $6 \mathrm{~b})$, respectively) using the Rayleigh tests, suggesting that this species may be cathemeral. Nevertheless, banteng tended to be more active at dusk than dawn $(\mathrm{p}=0.012)$, with a mean activity time of $16: 42 \pm 18: 48$ circular stdev. There was no significant difference in number of encounters between day and night time in both wet and dry seasons $(\chi 2=2.43, \mathrm{df}=1, \mathrm{p}=0.119$; and $\chi 2=3.38, \mathrm{df}=1, \mathrm{p}=0.227$, respectively).

The number of activities occurred at four moon phases shows indistinct differences from one to another, where the highest activity is between 17.00 and 18.00 . This finding is also supported by the statistical test showing that there is no significant difference in activities between four moon phases 

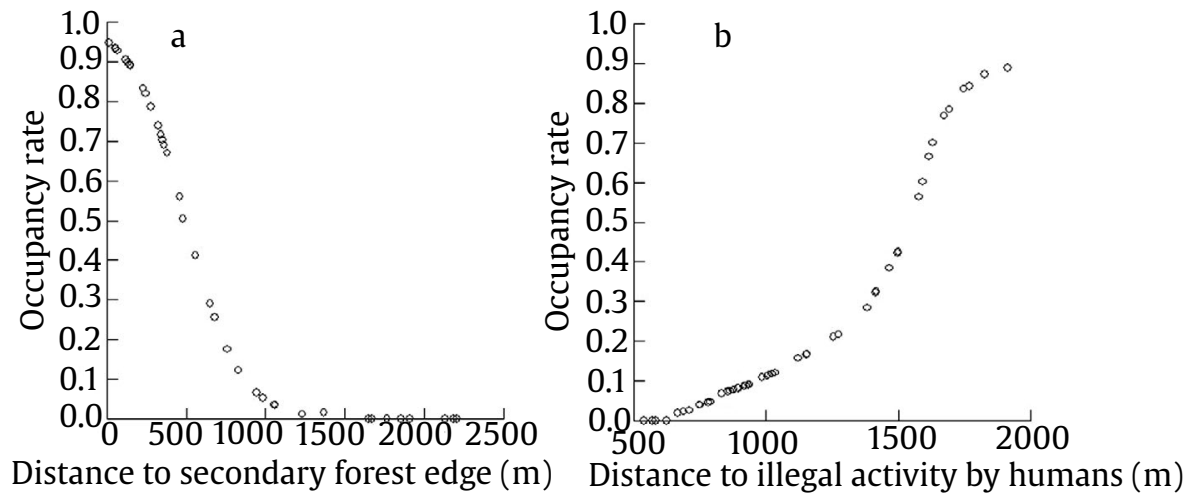

Distance to secondary forest edge $(\mathrm{m})$
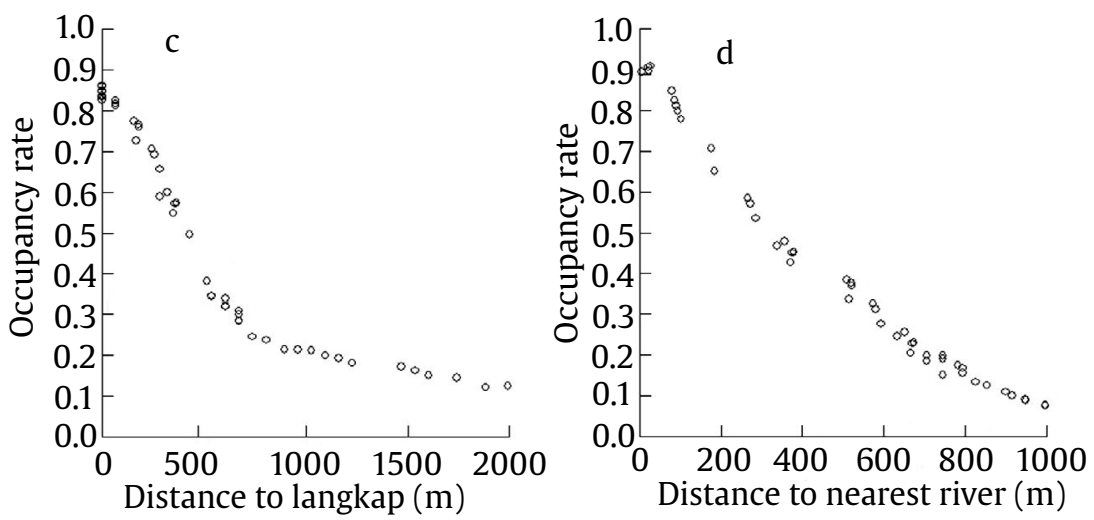

Figure 3. Relationship between occupancy of the tropical lowland forest, Ujung Kulon National Park, Banten, Indonesia, by Bos javanicus and distance to secondary forest edge (a) and distance to the nearest illegal activity by human (b) in wet season. Relationship between occupancy of the tropical lowland forest, Ujung Kulon National Park, Banten, Indonesia, by Bos javanicus and distance to invasive of palm species: Langkap Arenga obtusifolia (c) and distance to the nearest river $(\mathrm{d})$ in dry season

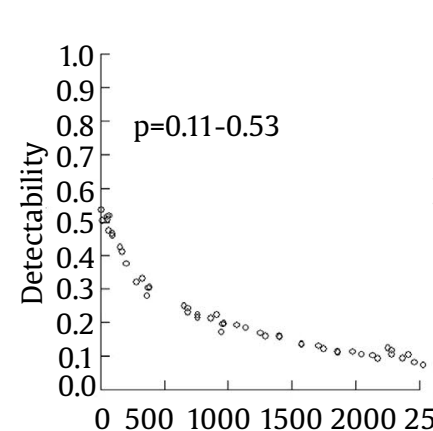

Distance to secondary forest edge (m)

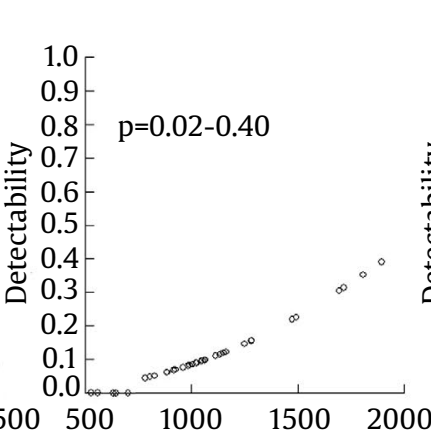

Distance to illegal activity by humans (m)

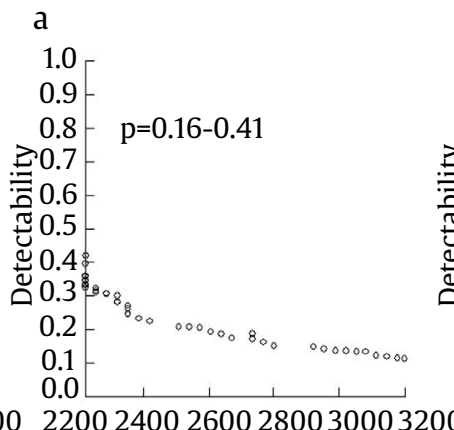

Rainfall of the wettest month (mm/year)

\section{b}

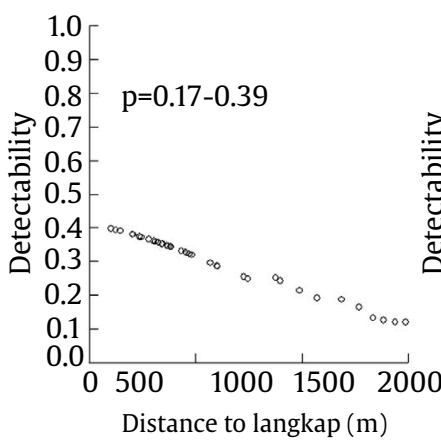

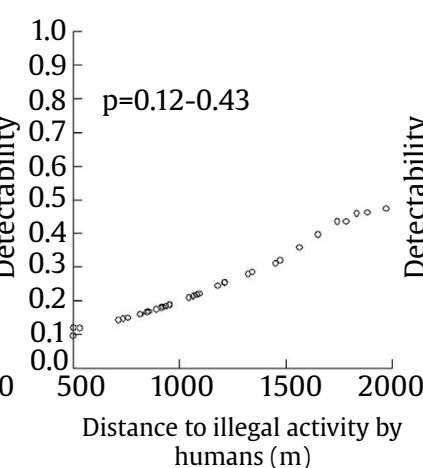

1.0

0.9

$0.8-\mathrm{p}=0.05-0.48$

$\gtrsim 0.7$

플 0.6

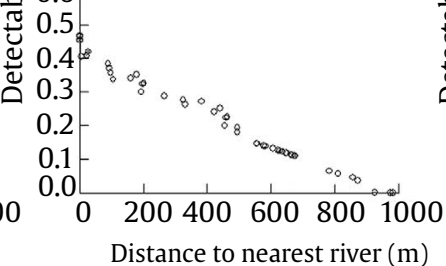

Distance to nearest river ( $\mathrm{m}$ )
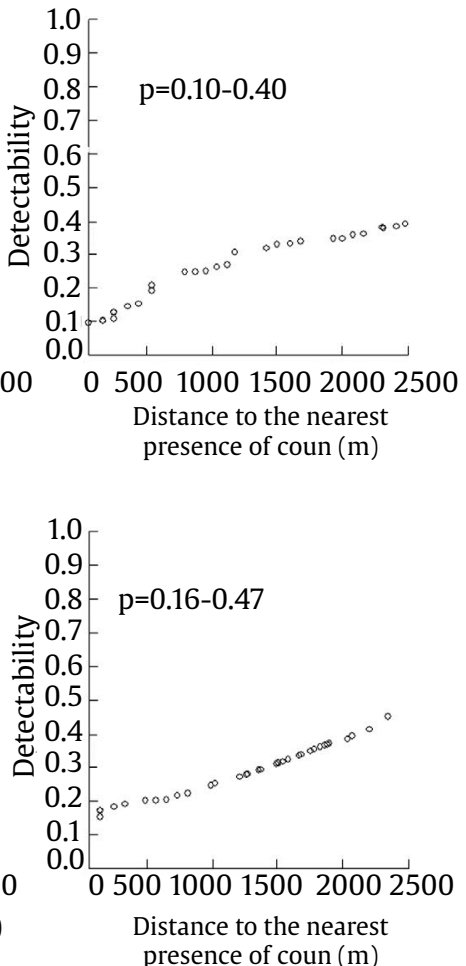

Figure 4. Relationship between detectability of Bos javanicus Ujung Kulon National Park, Banten, Indonesia (a) in wet season, and (b) dry season 
Table 4. Overlap coefficient $\left(\Delta_{4}\right)$ between prey-predator activity patterns, 95\% confidence intervals (95\% Cis), and Mardia-Watson-Wheeler (MWW) test

\begin{tabular}{llll}
\hline & $\Delta_{4}(95 \% \mathrm{ci})$ & MWW & $p$ value \\
\hline Banteng $\times$ Javan & $0.56(0.53-0.59)$ & 39.45 & $<0.0001^{* *}$ \\
leopard & & & \\
Banteng $\times$ Dholes & $0.69(0.66-0.72)$ & 8.30 & $<0.05^{*}$ \\
\hline
\end{tabular}

The $p$ value of less than 0.05 indicate that the two sets of circular distributions come from different distribution
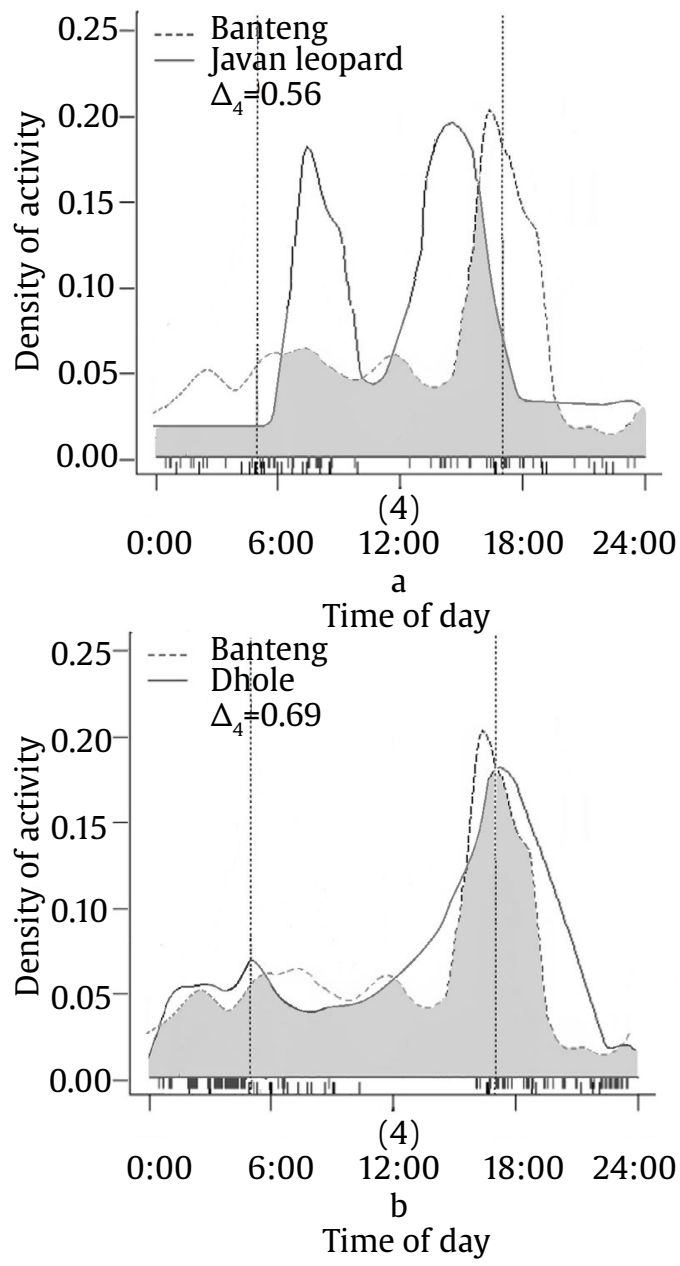

Figure 5. Daily activity patterns and overlap of (a) bantengJavan leopard, and (b) banteng-Dhole

( $F=0.328$; df $1=3$, df $2=92$, p-value $=0.805$, Figure $7 a)$. On full moon phase (FM), there is no meaningful increase in activities during the night which is also supported by the statistical test $(t=1.073$, d.f. $=1$, $\mathrm{p}$-value $=0.295$, Figure $7 \mathrm{~b}$ ) .

Our finding shows that activities such as excretion, locomotion, ingestive and vigilant are found to be positively-strongly correlated indicating these activities tend to happen at the same times. Some activities such as excretion, resting and vigilant, however, show a negative association with social

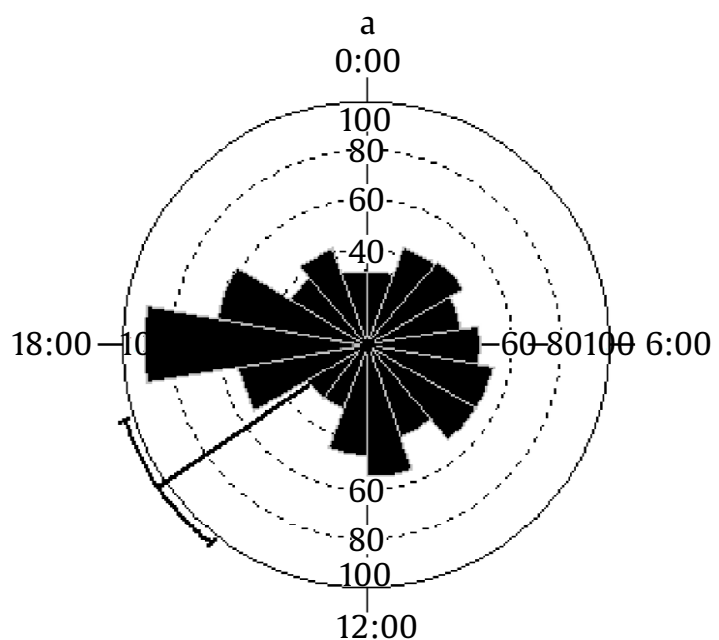

Time (hours)

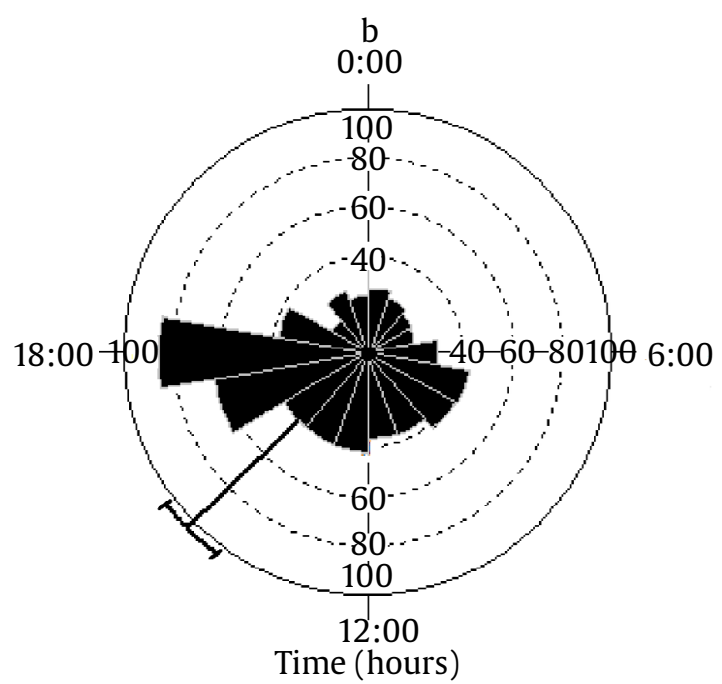

Figure 6. Activity plots based on camera trap records of Bos javanicus (a) in wet saeson and (b) in dry season

activity explaining that they occur in the different time with social activity. We found two points of time where the activities rate reaches its peak (between 17.00-19.00). In the night time variable, we found only ingestive activity receives significant effects where it indicates the species tend to do ingestion during the day, the sign of parameter is negative. The correlogram matrix displays the interaction between activities for 24 hours (Figure 8).

Overall, bantengs appeared in small family groups (with or without males), pairs, or as a single male. Changes in group structure over the year indicate a peak of the reproductive stage in the wet season, particularly in January (Figure 9). The mean group size, mean litter size, and group combination are shows in Table 5. 


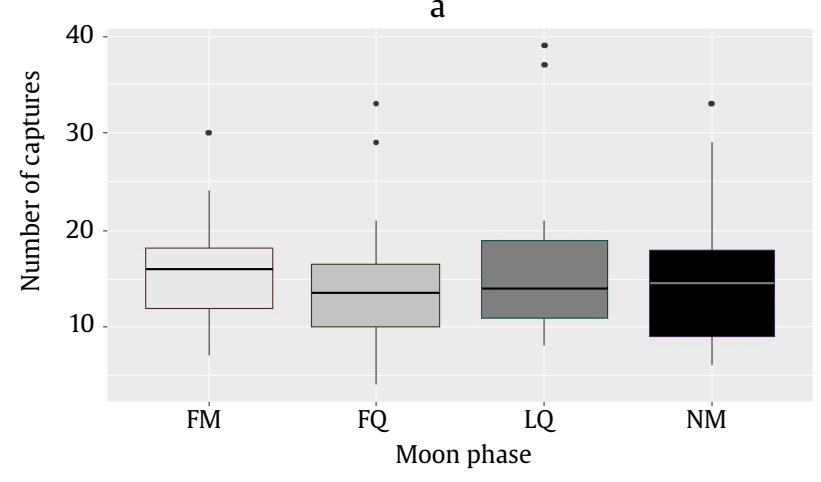

b

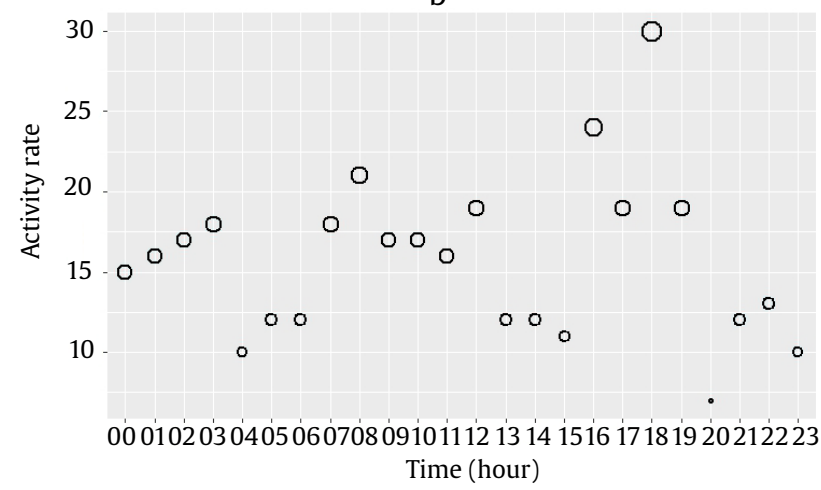

Figure 7. The number of Bos javanicus activities occurred at four moon phases (a) and the number of activities on full moon phase within 24 hours during a year (b)

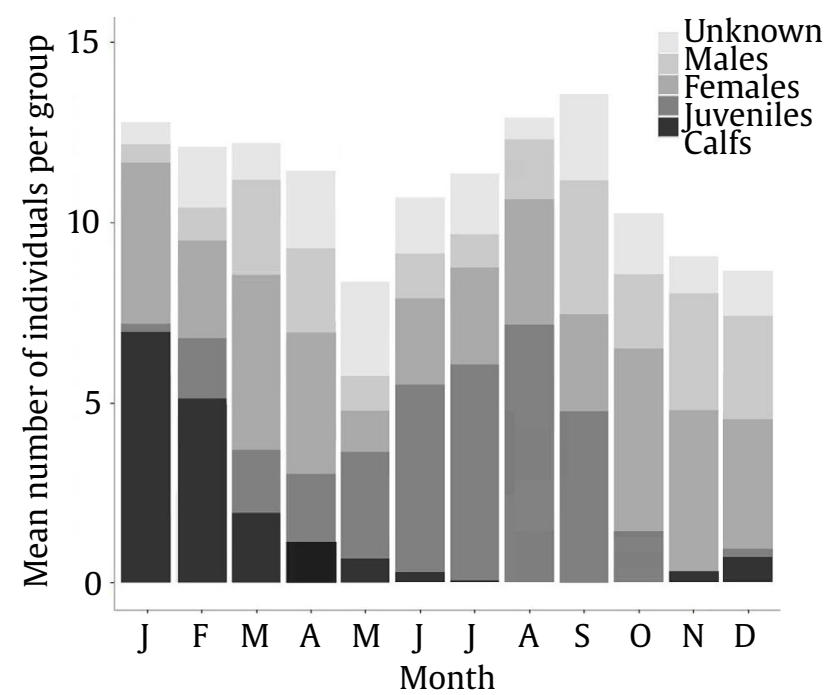

Figure 9. Annual patterns in group size and structure based on camera trap records of Bos javanicus

Table 5. Mean group size, mean litter size and group combinations of banteng (Bos javanicus) recorded in 30-second videos in December 2015-January 2017

\begin{tabular}{ll}
\hline Parameters & \\
\hline N of videos & 1461 \\
Mean group size $\pm s d$ (range) & $7.54 \pm 6.50(1-15)$ \\
Litter size \pm sd (range) & $3.38 \pm 2.14(1-6)$ \\
& $(\mathrm{n}=269)$ \\
Number of adult females (range) & $2.65 \pm 1.98(0-7)$ \\
Number of adult males (range) & $1.18 \pm 0.44(0-3)$ \\
Number of unknown adults (range) & $2.10 \pm 1.04(0-6)$ \\
\hline
\end{tabular}
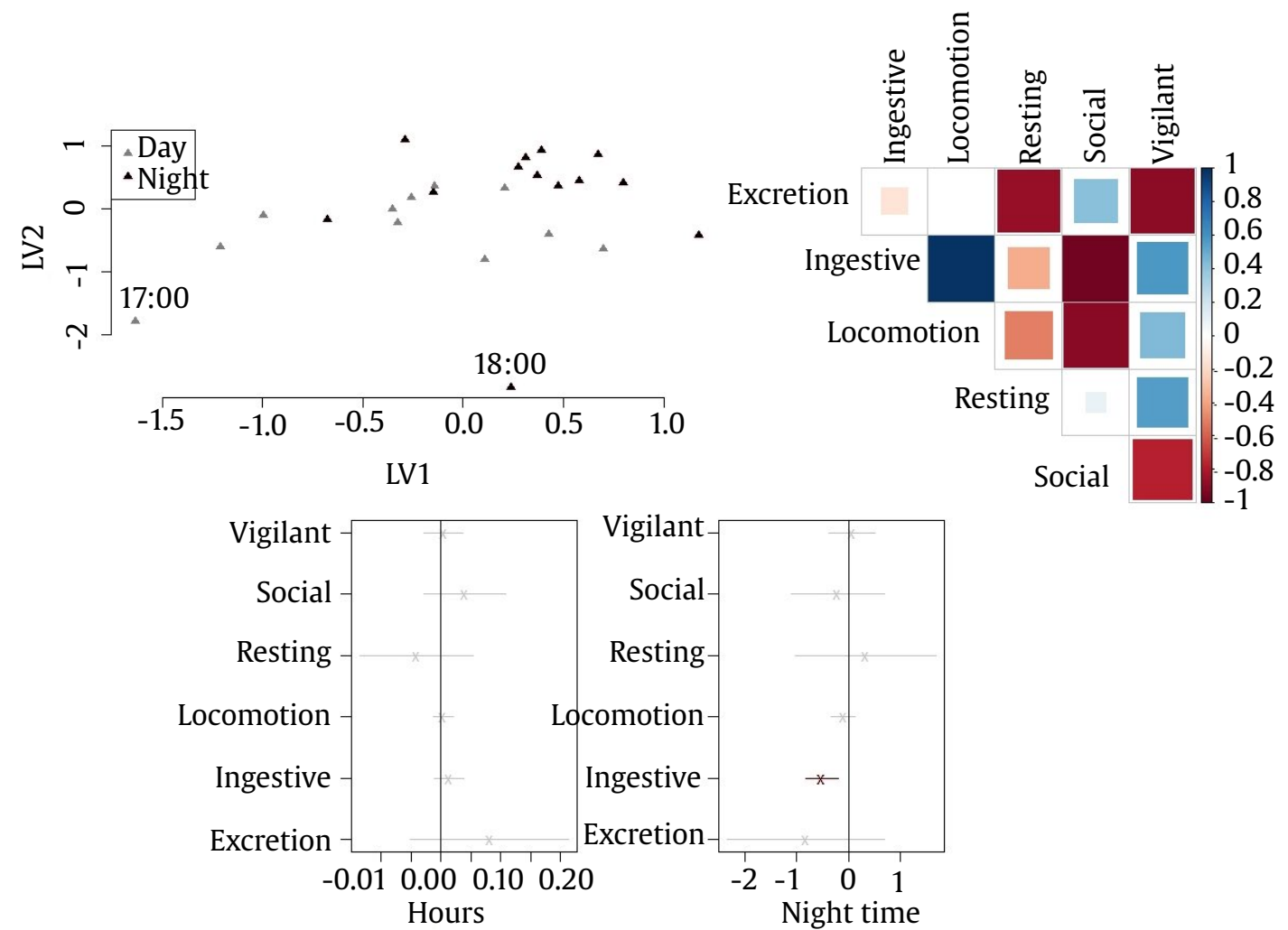

Figure 8. The distribution of total kind of activities in 24 hours during 2016 by Bos javanicus 


\section{Discussion}

Although our data covers only a single national park on the western tip of Java Island, the robust sampling design and the variety of surveyed habitats support a more considerable extent to our results. This may constitute a basic knowledge for other areas in Java and the whole species' range.

We detected banteng almost at all sites in the photographs, including sites where no banteng has been reported before. Using occupancy models, we have been identifying suitable habitat for bantengs to establish conservation priorities for the species in the UKNP. Through this study, we proposed the conservation priority of banteng's habitat that integrates occupancy models and landscape information at local scale for the first time. Identifying areas in wet and dry seasons with high presences of banteng population will be a valuable information tool to determine conservation priority areas in UKNP. It includes subsequently direct ranger patrols, anti-poaching efforts, and anti-encroachment operations. The suitability distribution areas generated by our models show occupancy areas of the high and low presence for banteng. Also, it provides an understanding of relevant natural and anthropogenic variables which support the occurrence of the banteng.

Our results showed the landscape and anthropogenic variables which best describe the occupancy of banteng in the UKNP. These results supported our predictions that banteng occupancy in UKNP was positively associated with the primary source of food and negatively with disturbance by humans. Our result showed a lower number of records in the wet season compared to the dry season, which possibly related to a lower level of activity caused by higher food availability in the secondary forest. Thus, the food and water source availability during the dry season is scarcer. This relative scarcity is leading to a broader movement of banteng to the rivers and langkap areas which increasing the encounter probability (Buchholz 1990; Rahman et al. 2017).

Several studies carried on in other regions have reported the association between banteng and its areas near water (Manh-Ha 2009). Thus, the highest occupancy rates and detectability of the banteng in the center portion of the UKNP attributed to the higher quantity of water portion in the park compared to the other portions of UKNP (i.e., south and west). Moreover, the distance to water was one of the covariates that best described the distribution of bantengs (Imron et al. 2016; Chaiyarat et al. 2018). Currently, UKNP is experiencing a lower water level during the dry season because lack of rainfall, they will use water sources such as rivers that still have water or use permanent wallows that are usually used by rhinos. Additionally, mineral licks are also an essential feature of banteng's habitat. At the coastal regions which lack minerals, animals licking behaviour will meet the mineral requirements by occasionally drinking seawater (Halder 1976).

Hommel (1987) recorded no palms Arenga obtusifolia (langkap) in UKNP in the 1980s, but it is abundant along the area nowadays (Hariyadi et al. 2012). Langkap is an invasive plants species and has grown dominantly in the area where the originals banteng food source occurred. We suspected langkap as an alternative food source for banteng. Previous studies have indicated langkap dominancy as a threat to rhinos' natural food availability (Nardelli 2016). Thus, occupancy and detectability models demonstrate high occurrence probabilities in such habitat areas.

UKNP is a national protected area (Ministry of Forestry 1992) and is the UNESCO World Heritage Site since 1991, but illegal pastures for livestock, forest encroachment, and poaching are still common practices in the area (UKNP 2017). As much as 299 cases of illegal activity occurred in the wet season (UKNP 2017). Other studies carried out at Baluran National Park (and also Meru Betiri NP and Alas Purwo NP) in East Java have shown that occupancy and abundance of this banteng are negatively correlated with the level of poaching (Pudyatmoko 2004). Based on the interview that we conducted with local people, they are ignoring the bantengs. Here, bantengs are not the hunting target because they only cause limited damage to crop in the surrounding area. The biggest threat for bantengs in UKNP is illegal livestock grazing activities which lead to zoonoses (Radcliffe et al. 2016; Khairani et al. 2018).

Besides illegal activity by humans, the distance to forested patches, rainfall and predation may also influence the detectability of banteng in UKNP. The high degree of rainfall and predation by dhole in the lowlands could be associated with the lowest rates of occupancy and detectability of bantengs (Rahman et al. 2018). Furthermore, the detectability of bantengs increased as the distance to deforested patches decreased, which indicated that bantengs accosted the sites nearest to deforested patches. In UKNP, dhole has a significant positive interaction and overlaps with the banteng, whereas banteng is captured as prey by dhole (Rahman et al. 2018). Dholes have the advantage of large-sized prey hunts because they are living in groups. We need to consider on the spatiotemporal interaction between dholes and banteng. This relationship was the only pair of species interaction which represented a strong 
negative spatial interaction and temporal segregation. Bantengs in the Baluran National Park is the only large mammal that exhibits significant negative spatial interaction with free-range livestock (Pudyatmoko 2017). Furthermore, dhole might be responsible for population declines of banteng in Alas Purwo National Park(Hedges and Tyson unpublished work). This finding indicates the banteng sensitivity to predation. Dholes' exhibit similar predator to prey ratios, in contrast to solitary hunters' Javan leopard (feed on the equal or slightly smaller size) (Hayward et al. 2014; Rahman et al. 2018). The pattern of movement and distribution of herbivore animals is in general strongly associated with predators. They tend to adjust the movement through the avoidance strategy (Flaxman et al. 2011; Rosier and Langkilde 2011).

Here, we found that bantengs are active both at night and during the day, which in line with the previous study in UKNP (Halder 1976; Timmins et al. 2008). Moreover, banteng in UKNP tended to be more active at dusk than dawn (mean activity time between 17:00-19:00). In undisturbed areas, banteng does not differentiate much in their activities pattern between day and night (Hoogerwerf 1970), which we can see in Baluran National Park and Alas Purwo National Park (Pudyatmoko 2005). Both in Baluran and Alas Purwo National Park, several groups graze in the open area at dusk until 08:00, and occasionally until 10:00. Afterwards, banteng will enter the forest to avoid the hot temperatures in the open area. They will come back to the open area in the afternoon (around 15:00) and stay until the evening. In contrast with the two locations above, differential use of habitat between day and night has not yet been documented for banteng in UKNP. Here, the individuals are resting and foraging in dense vegetation throughout the day. Only if in some periods the food is abundant in the open area (such as pasture), banteng will utilise this location. Our finding shows that excretion, locomotion, ingestive, resting, socialising, and vigilant are roughly identical during both the day and the night in 24 hours in a year.

Since our results showed bantengs activities within 24 hours a year with no differences, it also showed no correlation between moon phase to bantengs activities. Bantengs became adaptable to be active in the evening, but they are not a nocturnal species. It is different than some nocturnal ungulates species which significantly increase the frequency of foraging during a particular moon phase (Pratas-Santiago et al. 2016; Traill et al. 2016). Banteng is known as ruminants that carry out foraging activities throughout the day. Ruminants have a unique digestive system which designed to ferment the digested food and provide precursors for energy, unlike monogastrics species such as swine and poultry (Orr et al. 2001).

Group composition of bantengs seems to be variable, with males sometimes staying in family groups when immatures are present. An old banteng usually leads each herd. Young bantengs form a herd with two or three individuals. Adult bantengs are solitary but enter a banteng herd for mating (Lekagul and McNeely 1988). Our mean group size of 3 (range 2-15) is significantly lower than the previously reported mean group size of 4 (2-30) (Lekagul and McNeely 1988; Gardner et al. 2014). The differences in the number of groups are possible due to differences in study areas. Most of the reported groups of bantengs are those that inhabit open areas such as pastures. In the open area, the banteng group appears to be a larger group size since it may be a combination of several small groups together in the open area. Supported by our study which explaining in detail the behaviour of banteng in open areas is to reduce threats by predators. Preys that live in larger groups can intimidate a predator by simultaneously mobbing it, driving the predators away before it can attack. Prey can also behave by signalling the predator, that it would be a waste of time and energy attempting an attack (Kie 1999; Rosier and Langkilde 2011).

Moreover, our data support the peak of reproduction phase which is showing the highest peak in the wet season (January and February), with no immatures observed during the end of the wet season (April and May). Increased reproduction in the peak of the wet season has been recorded from Cambodians living within Banteng habitat, which suggested that the majority of births occurred in December and January (S. Hedges unpubl data 1991-2002).

\section{Conclusions}

Ultimately, we propose the findings of our study to facilitate more effective and reliable occupancy monitoring of banteng in UKNP. Accurate patchspecific occupancy data will enhance our knowledge of the species distribution, enable tracking changes in population status, assist in the selection of additional management focal areas, and facilitate monitoring responses to habitat management. Therefore, we recommend our survey protocol and recommendations to be incorporated into an adaptive management 
program for the species. Our findings also provide insight into the role of detection in monitoring rare and cryptic banteng that occupy dense habitats. Our approach may be useful in developing monitoring programs for conservation concern of other species, for which accurate patch-level data on occupancy status are necessary for conservation management. Moreover, further research is required to provide information for long-term conservation planning such as 'Project Banteng', akin to 'Project Rhino' and 'Project Elephant', for the future survival of the species.

\section{Acknowledgements}

We wish to thank the team of Rhino Monitoring Unit (RMU) in Ujung Kulon National Park, Ministry of Environment and Forestry, the Republic of Indonesia who contributed to data collection.

\section{References}

Bakker ES et al. 2015. Assessing the role of large herbivores in the structuring and functioning of freshwater and marine angiosperm ecosystems. Ecography 39:162179. DOI:10.1111/ecog.01651

Batschelet E. 1981. Circular Statistics in Biology. London: Academic Press.

Buchholtz C. 1990. Cattle. In Grzimek's Encyclopedia of Mammals. Edited by S Parker. New York: McGrawHill. pp. 360-417.

Burnham K, Anderson D. 2002. Model Selection and Multimodel Inference: a Practical Information and Theoretic Approach. $2^{\text {nd }}$ ed. New York: Springer.

Caraka RE et al. 2018. Ecological show cave and wild cave: negative binomial gllvm's arthropod community modelling. Procedia Comput Sci 135:377-388. DOI:10.1016/j.procs.2018.08.188

Chaiyarat $\mathrm{R}$ et al. 2018. Habitat and food utilization by banteng (Bos javanicus d'Alton 1823) accidentally introduced into the Khao Khieo-Khao Chomphu Wildlife Sanctuary, Thailand. Mammalia 82:23-34. DOI:10.1515/mammalia-2016-0121.

De la Torrea JA et al. 2018. Assessing occupancy and habitat connectivity for Baird's tapir to establish conservation priorities in the Sierra Madre de Chiapas, Mexico. J Nat Conserv 41:16-25. DOI:10.1016/j.jnc.2017.10.004

Di Marco M et al. 2014. A retrospective evaluation of the global decline of carnivores and ungulates. Conserv Biol 28:1109-1118. DOI:10.1111/cobi.12249

Dröge E et al. 2017. Risky times and risky places interact to affect prey behaviour. Nat Ecol Evol 1:1123-1128. DOI:10.1038/s41559-017-0220-9

Fauzi AI, Stoops G. 2004. Reconstruction of a toposequence on volcanic material in the Honje Mountains, Ujung Kulon Peninsula, West Java. Catena 56:45-66. DOI:10.1016/j.catena.2003.10.004

Fernández-Durán JJ. 2004. Circular distributions based on nonnegative trigonometric sums. Biometrics 60:499503.
Flaxman SM et al. 2011. Evolutionary ecology of movement by predators and prey. Theor Ecol 4:255-267. DOI:10.1007/s12080-011-0120-6

Gardner PC et al. 2014. Banteng Bos javanicus d'Alton, 1823. In: Melletti M, Burton J eds. Ecology, Evolution and Behaviour of Wild Cattle: Implications for Conservation. USA: Cambridge University Press.

Gardner PC et al. 2016. Bos javanicus. The IUCN Red List of Threatened Species 2016:e.T2888A46362970. D O I : 10.2305 / I U C N. UK. 2016 - 2 . R L T S. T2888A46362970.en

Giachetti T et al. 2012. Tsunami hazard related to a flank collapse of anak Krakatau Volcano, Sunda Strait, Indonesia. Geol Soc 361:79-90. DOI:10.1144/SP361.7

Halder U. 1976. Okologie and Verhalten Des Banteng (Bos javanicus) in Java. Hamburg and Berlin: Verlag Paul Parey.

Hansen BB et al. 2009. Functional response in habitat selection and the tradeoffs between foraging niche components in a large herbivore. Oikos 118: 859-872. DOI: $10.1111 /$ j.1600-0706.2009.17098.x

Hariyadi ARS et al. 2012. Optimizing the habitat of the Javan rhinoceros (Rhinoceros sondaicus) in Ujung Kulon National Park by reducing the invasive palm Arenga obtusifolia. Pachyderm 52: 49-54.

Haryono $\mathrm{M}$ et al. 2014. Monitoring of the Javan rhino population in Ujung Kulon National Park, Java. Pachyderm 56: 82-86.

Hayward MW et al. 2014. Diet and prey preferences of dholes (Cuon alpinus): dietary competition within Asia's apex predator guild. JZool Lond 294:255-266. DOI:10.1111/ jzo.12171

Hommel PWFM. 1987. Landscape-ecology of Ujung Kulon (West Java, Indonesia) [Dissertation]. Wageningen, Belanda: Wageningen University.

Hoogerwerf A. 1970. Udjung Kulon, The Land of The Last Javan Rhinoceros. E. J. Brill-Leiden: The Netherlands.

Hui et al. 2015. Model-based approaches to unconstrained ordination. Methods in Ecol Evol 6:399-411. DOI:10.1111/2041-210X.12236

Imron MA et al. 2016. The use of habitat suitability index map for designing population monitoring of banteng (Bos javanicus) in Alas Purwo National Park-East JavaIndonesia. AJCB 5:31-39.

IUCN. 2018. The IUCN red list of threatened species. Version 2018-2. Available at: http://www.iucnredlist.org [Data accessed: 18 November 2018]

Jarvis A et al. 2008. Hole-filled SRTM for the Globe Version 4, Available from the CGIAR-csi SRTM 90m Database. Available at: http://srtm.csi.cgiar.org. [Data accessed: 14 July 2018]

Jones CG et al. 1994. Organisms as ecosystem engineers. Oikos 69:373-386. DOI:10.2307/3545850

Khairani KO et al. 2018. Surveillance for hemorrhagic septicemia in buffalo (Bubalus bubalis) as an aid to range expansion of the Javan rhinoceros (Rhinoceros sondaicus) in Ujung Kulon National Park, Indonesia.J Wildl Dis 54:14-25. DOI:10.7589/2015-07-183

Kie JG. 1999. Optimal foraging and risk of predation: effects on behavior and social structure in ungulates. $J$ Mammal 80:1114-1129. DOI:10.2307/1383163

Lekagul B, McNeely JA. 1988. Mammals of Thailand, $2^{\text {nd }}$ ed. Association for the Conservation of Wildlife. Bangkok: Darn Sutha. pp 758. 
MacKenzie DI, Royle JA. 2005. Designing occupancy studies: general advice and allocating survey effort.J Appl Ecol 42:1105-1114.DOI:10.1111/j.1365-2664.2005.01098.x

MacKenzie DI et al. 2006. Occupancy Estimation and Modeling: Inferring Patterns and Dynamics of Species Occurrence. San Diego: Elsevier.

Manh-Ha N. 2009. The status of gaur Bos gaurus and banteng Bos javanicus in Ea So Nature Reserve and Yok Don and Cat Tien National Parks, Vietnam. Oryx 43:1-7. DOI:10.1017/S0030605307000440

Medway L. 1969. The Wild Mammals of Malaya. Kuala Lumpur: Oxford University Press.

Meredith M, Ridout M. 2014. Overlap: estimates of coefficient of overlapping for animal activity patterns. $R$ package version 0.2.7. Available at: https://cran.r-project.org/ web/packages/overlap/index.html [Data accessed: 24 August 2018]

Ministry of Forestry. 1992. Keputusan Menteri Kehutanan No. 284/Kpts-II/1992 tentang Perubahan Fungsi Cagar Alam Gunung Honje, Cagar Alam Pulau Panaitan, Cagar Alam Pulau Peucang, dan Cagar Alam Ujung Kulon menjadi Taman Nasional Ujung Kulon.

Ministry of Environment and Forestry. 2015. Keputusan Direktur Jenderal Konservasi Sumber Daya Alam dan Ekosistem No. SK. 180/IV-KKH Tahun 2015 tentang penetapan dua puluh lima satwa terancam punah prioritas untuk ditingkatkan populasinya sebesar 10\% pada tahun 2015-2019. Sekretariat Kabinet RI, Jakarta, Indonesia.

Ministry of Environment and Forestry. 2018. Peraturan Menteri Lingkungan Hidup dan Kehutanan Republik Indonesia No. P.106/MENLHK/SETJEN/KUM.1/12/2018 tentang perubahan kedua atas peraturan Menteri Lingkungan Hidup dan Kehutanan No. P.20/MENLHK/ SETJEN/KUM.1/6/2018 tentang jenis tumbuhan dan satwa yang dilindungi. Sekretariat Kabinet RI, Jakarta, Indonesia.

Mondal K et al. 2012. Prey selection, food habits and dietary overlap between leopard Panthera pardus (Mammalia: Carnivora) and re-introduced tiger Panthera tigris (Mammalia: Carnivora) in a semi-arid forest of Sariska Tiger Reserve, Western India. Ital J Zool 79:607-616. DOI:10.1080/11250003.2012.687402

Nardelli F. 2016. Current status and conservation prospects for the Javan rhinoceros Rhinoceros sondaicus Desmarest 1822. International Zoo News 63:180-202.

Niedballa J et al. 2016. camtrapR : an R package for efficient camera trap data management. Methods Ecol Evol 7:1457-1462. DOI:10.1111/2041-210X.12600

Niku J et al. 2017. Gllvm: R package version 0.1.0.

Nowak R. 1999. Walker's Mammals of the World. $6^{\text {th }}$ ed. Baltimore: The John Hopkins University Pres.

O'Brien TG et al. 2003. Crouching tigers, hidden prey: Sumatran tiger and prey populations in a tropical forest landscape. Anim Conserv 6:131-139. DOI:10.1017/S1367943003003172

Orr RJ et al. 2001. Matching grass supply to grazing patterns for dairy cows. Grass Forage Sci 56:352-361. DOI:10.1046/j.1365-2494.2001.00284.X

Pratas-Santiago LP et al. 2016. The moon cycle effect on the activity patterns of ocelots and their prey. J Zool 299:275-283. DOI:10.1111/jzo.12359

Prugh LR et al. 2019. Designing studies of predation risk for improved inference in carnivore-ungulate systems. Biol Conserv 232:194-207. DOI:10.1016/j. biocon.2019.02.011
Pudyatmoko S. 2004. Does the banteng (Bos javanicus) have a future in Java? Challenges of the conservation of a large herbivore in a densely populated island. Knowledge Marketplace Reports of the $3^{\text {rd }}$ IUCN World Conservation Congress. Bangkok: IUCN. pp. 6.

Pudyatmoko S. 2005. Freilanduntersuchungen zur Ökologie und Habitatnutzung Wildlebender Banteng Rinder (Bos javanicus) im Baluran National Park in Ost Java, Indonesien [Dissertation]. Göttingen, Jerman: University of Goettingen.

Pudyatmoko S. 2017. Free-ranging livestock influence species richness, occupancy, and daily behaviour of wild mammalian species in Baluran National Park, Indonesia. Mamm Biol 86:33-41. DOI:10.1016/j. mambio.2017.04.001

Pudyatmoko S. 2018. Spatiotemporal inter-predator and predator-prey interactions of mammalian species in a tropical savanna and deciduous forest in Indonesia. Mamm Res 64:191-202. DOI:10.1007/s13364-0180391-z

Radcliffe RW et al. 2016. Tabanid Fly Vector Biology Driving Trypanosome Infection in Ujung Kulon National Park, Indonesia. New York: Cornell University College of Veterinary Medicine.

Rahman DA et al. 2017. Factors affecting seasonal habitat use and predicted range of two tropical deer in Indonesian rainforest. Acta Oecol 82:41-51. DOI:10.1016/j. actao.2017.05.008

Rahman DA et al. 2018. Density and spatial partitioning of endangered sympatric Javan leopard (Felidae) and dholes (Canidae) in a tropical forest landscape. Folia Zool 67:207-219. DOI:10.25225/fozo.v67.i3-4.a8.2018

Ridout MS, Linkie M. 2009. Estimating overlap of daily activity patterns from camera trap data. J Agric Biol Environ Stat 14:322-337. DOI:10.1198/jabes.2009.08038

Ripple WJ et al. 2015. Collapse of the world's largest herbivores. Sci Adv 1:1-12. DOI:10.1126/sciadv.1400103

Ripple WJ et al. 2016. Bushmeat hunting and extinction risk to the world's mammals. $R$ Soc Open Sci 3:1-16. DOI:10.1098/rsos.160498

Rosier RL, Langkilde T. 2011. Behavior under risk: How animals avoid becoming dinner. Nature Education Knowledge 2:8.

Rowcliffe HM et al. 2014. Quantifying levels of animal activity using camera trap data. Methods Ecol Evol 5:1170-1179. DOI:10.1111/2041-210X.12278

Serrano J.2011. Calendario Astrológico lunar. Available at: http:/ calendario-lunar.com/?id=zonas; $t=S T O R Y ;$ topic=con [Data accessed: 8 November 2018]

Timmins RJ et al. 2008. Bos javanicus. In: IUCN, 2010. IUCN Red List of Threatened Species. Version 2010.4. Available at: www.iucnredlist.org [Data accessed: 22 February 2019]

Traill LW et al. 2016. Lion proximity, not moon phase, affects the nocturnal movement behaviour of zebra and wildebeest.JZool 299:221-227. DOI:10.1111/jzo.12343

UKNP [Ujung Kulon National Park]. 2017. Statistic of UKNP. Ministry of Environmental and Forestry, Indonesia.

Waldram MS et al. 2008. Ecological engineering by a megagrazer: White rhino impacts on a South African Savanna. Ecosystems 11:101-112. DOI:10.1007/ s10021-007-9109-9

Warton DI et al. 2015. So many variables: Joint modeling in community ecology. Trends in Ecology and Evolution 30:766-779. DOI:10.1016/j.tree.2015.09.007 